\title{
Inequality and Real Income Growth for Middle and Low-income Households Across Rich Countries in Recent Decades
}

\author{
Brian Nolan $^{a}$ and Stefan Thewissen ${ }^{b}$ \\ ${ }^{a}$ INET, Department of Social Policy and Intervention, Nuffield College, University of Oxford \\ ${ }^{b}$ Employment, Labour and Social Affairs Directorate, OECD
}

\begin{abstract}
This paper places what has happened to income inequality in rich countries over recent decades alongside trends in median and low incomes in real terms, taken as incomplete but valuable indicators of the evolution of living standards for 'ordinary working families' and the poor. The findings demonstrate first just how varied country experiences have been, with some much more successful than others in generating rising real incomes around the middle and towards the bottom of the distribution. This variation is seen to be only modestly related to the extent to which income inequality rose, which itself is more varied across the rich countries than is often appreciated. The extent to which economic growth is transmitted to the middle and lower parts of the distribution is seen to depend on a range of factors of which inequality is only one. Sources of real income growth around the middle have also varied across countries, though transfers are consistently key towards the bottom. The diversity of rich country experiences should serve as an important corrective to a now-common 'grand narrative' about inequality and stagnation based on the experience of US.
\end{abstract}

Keywords: Inequality, Poverty, Living Standards

* This paper is from the Employment, Equity and Growth research programme at the Institute for New Economic Thinking, Oxford Martin School, University of Oxford; support from the Resolution Foundation and Citi is gratefully acknowledged. 


\section{Inequality and Real Income Growth for Middle and Low-income Households Across Rich Countries in Recent Decades}

\section{Introduction}

The US has seen a dramatic rise in income inequality from an already high base since the late 1970s: the share of total income (before tax) going to the top 1\% has approximately doubled from around $10 \%$ to $20 \%$, according to estimates in the World Inequality Database, and the Gini coefficient measuring inequality in disposable income across the entire distribution has also risen markedly. This has gone together with stagnation in real incomes for much of the distribution: median income was only about $10 \%$ higher in real terms in the mid-2000s than it had been around 1980 (Proctor et al., 2016), and a substantial proportion of that very modest gain was then lost in the Great Recession and only recovered slowly. At the same time, poverty measured either in purely relative income terms or vis-à-vis the official US poverty threshold fixed in real terms is at a similar level now to in the early 1980s (Chaudry et al, 2016).

The contrast between the reasonably strong levels of aggregate economic growth that the US achieved over this period and stagnation in household incomes across much of the distribution has been highlighted in for example the Economic Report of the President, (2015); Fixler and Jaditz, (2002); Fixler and Johnson (2014); and Jorgenson and Slesnick, (2014). This has been central to a 'grand narrative' that has emerged linking stagnating ordinary living standards and a 'squeezed middle' to rising inequality, taking the US as exemplar but often now applied across the rich countries more generally in current debates about inequality, stagnation and their economic, social and political consequences. (See for example Tóth, 2014, on the narrative about rising inequality, Stiglitz 2012, 2015; Reich, 2015; OECD, 2015; Boushey, 2019, on its economic impacts, and Nolan and Valenzuela, 2019, for an overview of and references to the wide-ranging literature on social and political impacts). It is noteworthy that the implications for poverty, on the other hand, have not featured prominently in these debates. 
Rising income inequality could affect the growth of middle incomes via several different routes. If those in the upper-middle or at the top receive an increasing share of total income, there must be a compensating decline in shares elsewhere; however, this could of course still represent a real increase in middle and lower incomes, depending on the overall rate of economic growth. A second potential channel is via the impact of inequality on economic growth itself. For many years the prevailing wisdom held that higher inequality provides the incentives required to drive economic growth. More recently, though, Stiglitz $(2012 ; 2015)$, IMF and OECD studies (Ostry et al., 2014; Cingano, 2014; OECD, 2015), and some prominent financial sector commentaries (Morgan Stanley, 2015; Standard and Poor's, 2014), among others, have suggested that rising income inequality may instead be damaging to growth. A wide range of different causal channels, with varying time-lags and dynamics, may be implicated (for an overview see Boushey, 2019). Rising top income shares may hold back consumer demand, since rich people save more. Middle and lower-income households may then borrow beyond their means to maintain consumption, fuelling boom-bust economic cycles. The shift in managerial reimbursement has also focused CEOs on short-term earnings targets and higher dividends or shares buybacks, so despite high profits firms are reluctant to invest. Higher inequality may reinforce the capacity of firms and their owners that dominate particular sectors to protect their excess profits and stifle competition and innovation. Greater inequality may also impede the capacity of middle and lower earners to invest in their own education and skill upgrading, and also lead to under-investment in the education of poorer children and increase barriers to socio-economic mobility between generations. Inequality may also undermine institutions that are critical for sustained growth, by increasing the voice of the wealthy and undermining trust in those institutions in the general population, undermining social cohesion, reducing voter turnout and increasing support for 'populist' parties. Concern about such damaging economic, social and political effects underpins the focus of the OECD 
and other multilateral organisations on "inclusive growth" and "shared prosperity" (de Mello and Dutz, 2012; OECD, 2015; World Bank, 2016; IMF, 2017).

Here, the core aim is to bring together what has happened to inequality in the distribution of income across households with trends in median and low incomes in real terms, to see how these have evolved and the extent to which they appear to be related. In pursuing this aim we draw on key findings from the recently published volume Generating Prosperity for Working Families in Affluent Countries (Nolan, 2018), and develop its investigation of low incomes in particular. Section 2 describes the comparative data to be employed. Section 3 sets out what these show about how income inequality has evolved. Section 4 correspondingly presents key findings on how real incomes around the middle of the distribution have, or have not, grown over time. Section 5 then examines the relationship between the two, and whether rising inequality appears to be associated with slower real income growth around the middle. Section 6 probes the transmission of GDP growth to 'ordinary' incomes in greater depth, to identify the most important 'leakages' in that transmission. Section 7 focuses on real incomes in the lower reaches of the distribution, examining how these have moved over time and how this relates to trends in the median, inequality, and economic growth. Finally, we discuss in Section 8 the implications for monitoring societal progress and for promoting prosperity.

\section{Measuring Income Inequality and Income Growth Across Rich Countries in Recent Decades}

While living standards and prosperity broadly conceived are the underlying concern, here we focus on household income as the best available proxy to capture variation across the rich countries over recent decades. Income has well-documented limitations as a measure of living standards, but crucially for comparative purposes it is available on a consistent basis across rich countries for recent decades. We take growth in real disposable income at the median as key reference point or benchmark for the evolution of "middle" living standards. We then take 
real income growth at the $10^{\text {th }}$. percentile (the income dividing the bottom $10 \%$ from the rest of the distribution, conventionally labelled $\mathrm{P}_{10}$ ) as an indicator of trends in the purchasing power of incomes among the poor (with the rationale for doing so to be brought out below). For comparative purposes, we also look at the income cutting off the bottom $30 \%, \mathrm{P}_{30}$, as an indicator of how real incomes have evolved for households well below the middle but not in poverty. With much of the generalized concern focused on the situation of "ordinary working people", particular emphasis is placed on how working age households, as distinct from older people, have fared, both around the middle and towards the bottom.

The measure of household disposable income from household surveys available over this span does not capture capital gains (or losses) on assets, or impute an income for the use value that home-owners obtain from owner-occupation. It also does not include the value of the services made available free or in subsidised form by the state, notably in education and health care, which are crucial to household living standards and quality of life, and affect how changes in household incomes are felt. While estimates of the value of these services to households at different points in the distribution have been made for some countries and time-points (see for example Garfinkel et al., 2006; Marical et al., 2006; Smeeding et al., 2008; Paulus et al., 2010, Verbist et al., 2012; Aaberge et al., 2013), this has not been done on a consistent basis across the rich countries over time, so this very important aspect of living standards cannot be directly incorporated into our analysis.

The income concept employed is total income of the household from all sources, including wages, self-employment income, income from capital, pensions, and social transfers, net of direct tax and employee social insurance contributions. In using household income as an indicator of trends in living standards, adjustment has to be made for differences in household size and composition, and for that purpose we employ the commonly-used square root of household size equivalence scale; while the choice of scale is somewhat arbitrary, it does not 
generally affect measured patterns of overall income growth over time. To capture changes in the purchasing power of nominal incomes over time, these are deflated using consumer price indices to produce changes in 'real' incomes. In using income to compare (absolute) living standards across countries, the Purchasing Power Parity (PPP) conversion factors produced by the International Comparison Program for 2011 are employed; while such estimates are subject to considerable debate, here the primary interest is in comparing real income growth across countries over time rather than levels at a point in time.

The nature of the data available for this analysis has major implications for the form it takes. The two core sources are the Luxembourg Income Study (LIS) and the OECD Income Distribution Database (Atkinson et al., 1995; OECD, 2008; 2011; 2012; 2015; Gornick and Jannti, 2013; Ravallion, 2015; Gasparini and Tornarolli, 2015). Both provide data on household incomes standardised, insofar as possible, across countries and over time, which is critical for this comparative analysis. The LIS database brings together micro-datasets from surveys for each country, whereas the OECD database comprises various measures related to incomes, inequality and poverty drawn from such surveys. LIS mostly has data in 'waves', for years around 1975, 1980, 1985 etc.; the OECD database also has figures at intervals for around 1980, 1985, etc, but has more annual data, especially from the mid-2000s. Most of the OECD countries are covered in both sources, but LIS allows one to go back as far as 1980 for more countries. Whereas most comparative studies on household incomes, inequality etc. rely entirely on one or the other of these data sources, here we draw on both to cover the longest period, and come up as far as possible, for each country. This means we mostly employ data from LIS, but use data from the OECD database for eight countries. ${ }^{1}$ While we go back as close

\footnotetext{
${ }^{1}$ These are New Zealand and Portugal, which are not included in LIS; Japan, for which LIS only has data for 1 year; Sweden, for which LIS has data only up to 2005; the Netherlands, for which the early waves in LIS are drawn from a different source, giving rise to what looks like a major break in the time-series; Greece, where LIS only starts in 1995 whereas OECD data goes back to 1986; Canada,
} 
to 1980 as possible, for quite a few countries we have to start later: for two-thirds of the countries covered it goes back at least as far as the mid/late-1980s, but for the remainder only a shorter period can be covered, sometimes considerably shorter. This varying coverage in terms of time-period maximises the span of countries and years included in the analysis but must be kept in mind in interpreting the differing growth rates then observed across countries. We exclude countries that are in the LIS database but are not OECD members and countries that are OECD members but generally categorised as middle-income (Chile, Mexico, and Turkey).

\section{What Has Happened to Income Inequality?}

We first set out what happened to income inequality for these countries over the period covered for each, in the data source we are using for each. ${ }^{2}$ Table 1 shows the period covered for each country, the Gini coefficient at the beginning and the end, and the overall change in the Gini; since the length of period covered varies across countries, the average annual change in the Gini is also shown. We see that some increase in the Gini coefficient was the most common experience across these rich countries in recent decades. However, there has been very wide variation in both the extent and timing of that increase. Some countries have seen little or indeed no increase, while others have seen rapid rises. Sweden, the UK and the USA had the most pronounced increases in inequality. Australia, the Czech Republic, Finland and New Zealand also saw marked increases, while Canada had a smaller but still substantial increase.

\footnotetext{
for which LIS only goes up to 2010 whereas the OECD database allows 2013 to be included; and South Korea, for which OECD goes up to 2014 whereas LIS has data only to 2012. For Belgium, LIS runs only up to 2000 and OECD from 2004-2013, so we link those two series to provides estimates that are necessarily tentative but allow us to include it in our analysis.

${ }^{2}$ LIS and the OECD IDD do not always show an identical picture for inequality levels or changes, nor do these always agree with other sources - see Nolan and Thewissen (2018b). The priority here is to ensure that the overall inequality measure and growth in the median and other percentiles are taken from the same source for each country and are in that sense internally consistent.
} 
Japan, Germany and the Netherlands saw some increase in inequality. Norway had a more modest rise, as did Italy and Spain. Austria, Denmark, France and, Ireland were among the minority of countries for which little or no increase in the Gini was seen. For the formerly state socialist and low-inequality countries, the picture is mixed, with some seeing large increases from their initially low levels of inequality. Overall, about two-thirds of the countries saw an increase in the Gini over the period covered by the data being used here for each. Focusing on working-age households only, one sees a similar pattern overall but a greater increase in inequality in some countries, notably Spain and the UK.

While a simple summary along the lines of "Income inequality increased in most rich countries in the decades up to the Crisis" is valid as far as it goes, it risks obscuring major, consequential differences in country experiences. The scale of increase in the Gini seen in the UK or USA versus Norway or Italy represent very different realities. Furthermore, a very substantial increase from a very low initial base level relative to other countries, as in the case of the Czech Republic, Finland or Sweden, may be very different in terms of how it makes itself felt to an increase of a similar scale from an already high level, as in the case most notably of the US.

This emphasis on the diversity of experiences is reinforced when one looks at the timing of inequality increases, which were often concentrated in specific sub-periods rather than smooth and consistent over time, as captured by Atkinson (2015) and Tóth (2014) highlighting their 'episodic' nature. The impact of the Great Recession on income inequality also varied widely across the rich countries, with inequality rising sharply in some but little changed in others. 
Table 1: Gini Coefficient from 1980 (or Nearest Available Year) to 2013 (or Nearest Available Year), Total Population

\begin{tabular}{|c|c|c|c|c|c|c|}
\hline Country & $\begin{array}{l}\text { First } \\
\text { Year }\end{array}$ & Last year & $\begin{array}{l}\text { Gini in } \\
1^{\text {st }} \text {. year }\end{array}$ & $\begin{array}{l}\text { Gini in } \\
\text { last year }\end{array}$ & $\begin{array}{l}\text { Change in } \\
\text { Gini }\end{array}$ & $\begin{array}{l}\text { Average Annual } \\
\text { Change }\end{array}$ \\
\hline Australia & 1981 & 2010 & 28.19 & 33.38 & 5.19 & 0.18 \\
\hline Austria & 1994 & 2013 & 28.18 & 28.07 & -0.12 & -0.01 \\
\hline Belgium & 1985 & 2013 & 22.79 & 26.19 & 3.40 & 0.12 \\
\hline Canada & 1980 & 2013 & 28.88 & 32.36 & 3.49 & 0.11 \\
\hline Czech Republic & 1992 & 2013 & 20.58 & 25.87 & 5.29 & 0.25 \\
\hline Denmark & 1987 & 2013 & 25.71 & 25.16 & -0.56 & -0.02 \\
\hline Estonia & 2000 & 2013 & 36.41 & 35.37 & -1.04 & -0.08 \\
\hline Finland & 1987 & 2013 & 20.70 & 26.11 & 5.41 & 0.21 \\
\hline France & 1978 & 2010 & 31.86 & 29.17 & -2.69 & -0.08 \\
\hline Germany & 1984 & 2013 & 26.60 & 29.48 & 2.89 & 0.10 \\
\hline Greece & 1986 & 2013 & 35.20 & 34.38 & -0.82 & -0.03 \\
\hline Hungary & 1991 & 2012 & 28.86 & 29.26 & 0.40 & 0.02 \\
\hline Iceland & 2004 & 2010 & 25.71 & 24.60 & -1.12 & -0.19 \\
\hline Ireland & 1987 & 2010 & 32.96 & 29.61 & -3.35 & -0.15 \\
\hline Israel & 1986 & 2012 & 31.01 & 37.32 & 6.30 & 0.24 \\
\hline Italy & 1986 & 2014 & 30.95 & 33.25 & 2.30 & 0.08 \\
\hline Japan & 1985 & 2012 & 30.45 & 33.00 & 2.55 & 0.09 \\
\hline Luxembourg & 1985 & 2013 & 23.60 & 28.36 & 4.76 & 0.17 \\
\hline Netherlands & 1977 & 2014 & 26.30 & 28.30 & 2.00 & 0.05 \\
\hline New Zealand & 1985 & 2012 & 27.10 & 33.30 & 6.20 & 0.23 \\
\hline Norway & 1979 & 2013 & 22.56 & 25.26 & 2.71 & 0.08 \\
\hline Poland & 1992 & 2013 & 26.22 & 32.20 & 5.98 & 0.28 \\
\hline Portugal & 2004 & 2013 & 38.19 & 34.51 & -3.69 & -0.41 \\
\hline Slovak Republic & 1992 & 2013 & 18.94 & 26.96 & 8.02 & 0.38 \\
\hline Slovenia & 1997 & 2012 & 22.93 & 27.11 & 4.17 & 0.28 \\
\hline South Korea & 2006 & 2014 & 30.60 & 30.24 & -0.36 & -0.05 \\
\hline Spain & 1980 & 2013 & 32.05 & 34.55 & 2.50 & 0.08 \\
\hline Sweden & 1983 & 2013 & 19.75 & 28.08 & 8.33 & 0.28 \\
\hline Switzerland & 2000 & 2013 & 28.54 & 29.61 & 1.07 & 0.08 \\
\hline United Kingdom & 1979 & 2013 & 26.71 & 33.37 & 6.66 & 0.20 \\
\hline United States & 1979 & 2013 & 31.15 & 38.28 & 7.13 & 0.21 \\
\hline Average & & & 27.73 & 30.41 & 2.68 & 0.11 \\
\hline
\end{tabular}

Source: LIS except OECD for Canada, Greece, Japan, Netherlands, New Zealand, Portugal, South Korea and Sweden, and for Belgium from 2004.

The (mostly) survey-based figures on overall income inequality in LIS and the OECD IDD may not adequately capture what has been happening at the very top, but the now widely-cited estimates of top income shares based on tax data and the national accounts, brought together in the World Inequality Database, provide a very valuable complement in that regard. These 
estimates cover only some of the rich countries being studied here, but for them Table 2 shows an increasing concentration of pretax income at the top in most in the decades up to the financial crisis. However, the scale of that increase again varied widely. It was greatest for the UK and the USA, followed by Canada and Australia, and Portugal and Sweden saw large rises. Finland, France, Germany, Italy, Japan, Korea, Norway and Spain also saw quite substantial increases, with smaller ones in the Netherlands, Switzerland, and New Zealand. The crisis is generally seen to have interrupted this upward trend, reflecting its impact on profits, top executive reimbursement, and the financial sector. For the USA, though, while the top $1 \%$ share fell quite sharply at the onset of the Crisis, it was back to its 2007 level by 2014. The trends shown by these estimates of top $1 \%$ shares do not always align with the measured changes in overall inequality across countries, for a variety of reasons explored elsewhere (including differences in income concept, income recipient unit, and data source) on which we cannot dwell here.

Table 2: Top 1\% Shares in Selected OECD Countries, 1980 Onwards

\begin{tabular}{|c|c|c|c|c|}
\hline & 1980 & 2007 & Change 1980-2007 & $\begin{array}{c}\text { Post-2007 value } \\
\text { (year) }\end{array}$ \\
\hline & $\%$ & $\%$ & $\mathrm{Ppt}$ & $\%$ \\
\hline Australia & 4.61 & 9.09 & +4.48 & 9.10 (2014) \\
\hline Canada & 8.88 & 15.63 & +6.75 & $13.62(2010)$ \\
\hline Denmark & 5.47 & 6.12 & +0.65 & $6.41(2010)$ \\
\hline Finland & 4.32 & 8.26 & +3.94 & 7.46 (2009) \\
\hline France & 8.17 & 11.69 & +3.52 & $10.80(2014)$ \\
\hline Germany & 10.72 & 14.04 & +3.32 & $12.98(2011)$ \\
\hline Ireland & 6.65 & 11.64 & +4.99 & 10.50 (2009) \\
\hline Italy & 6.90 & 9.86 & +2.96 & 9.38 (2009) \\
\hline Japan & 8.36 & 11.35 & +2.99 & $10.44(2009)$ \\
\hline Korea & 7.47 & 11.28 & +3.61 & $12.33(2012)$ \\
\hline Netherlands & 5.85 & 7.57 & +1.72 & $6.33(2012)$ \\
\hline New Zealand & 5.65 & 7.83 & +2.18 & 8.09 (2014) \\
\hline Norway & 4.60 & 8.54 & +3.94 & $7.80(2011)$ \\
\hline Portugal & 4.32 & 9.77 & +5.45 & \\
\hline Spain & 7.63 & 11.24 & +3.61 & 8.58 (2012) \\
\hline Sweden & 4.13 & 9.95 & +5.82 & $8.73(2013)$ \\
\hline Switzerland & 8.40 & 10.91 & +2.51 & $10.62(2010)$ \\
\hline United Kingdom & 6.67 & 15.44 & +8.77 & $13.8892014)$ \\
\hline USA & 11.05 & 19.87 & +8.82 & $20.20(2014)$ \\
\hline
\end{tabular}

Source: World Inequality Database 
The factors driving income inequality upwards, albeit at differing rates, across many rich countries have been reviewed in for example Förster and Tóth (2015), Nolan and Förster (2018) and Nolan (2018). These include increasing earnings dispersion among employees, primarily reflecting the widening in economic returns to education and skills, with globalisation and skillbiased technological change interacting with one other. Institutions and policies with respect to minimum wages and labour and product market deregulation, and declining union density and power, are also important. Changes in top executives pay and the expanded role of finance were very important in the growth in top incomes. Income from self-employment and capital have grown in importance and become more unequally distributed, with a shift from wages to profits common. Changes in household structures due to population ageing and the trend towards smaller households have also contributed. Assigning weights to specific factors in terms of their relative importance is extremely challenging, giving the limited data available and range of potential contributory factors (as brought out effectively by Förster and Tóth (2015); this also makes it very difficult to robustly identify the factors accounting for differences across countries in the way inequality has evolved, though contexts, institutions and policies clearly play a central role.

\section{Growth in Middle Incomes}

Against this background, what happened to real incomes around the middle of the distribution? Table 3 repeats for each country the years covered by the data employed, then shows the overall increase in the median in real terms and the annual average growth rate over that period. The most striking feature of these figures is the very wide range of variation across countries in real income growth at the median. For countries where the data covered at least several decades, the (compound) average annual growth observed over those decades ranges from as high as $3 \%$ down to a modest decline. The average growth rate across all the countries/time-periods covered is about $1 \%$. The US, where the data cover all the way from the late 1970 s to 2013 , 
had an average annual growth rate of only $0.3 \%$. It is not unique in that respect: Japan did even worse, seeing essentially no overall increase in the median (measured from 1985), while Italy (measured from 1986) saw as little overall growth as the US. However, these countries were amongst the poorest performers in the OECD. The US is far from typical in terms of this key indicator: to highlight just one contrast, the UK is often categorised alongside the US as a 'liberal/Anglo-Saxon' economy. but the US median was only 12\% higher in real terms in 2013 than it had been in 1979, whereas the UK median went up by almost $70 \%$ over the same period. These represent very different realities for middle-income households.

As well as varying across countries, median income growth varied widely over time for most countries. There were certain periods of reasonably healthy growth even for the poorest performers overall. The USA had the 'Clinton boom' in the 1990s, Japan some growth in the early 1990s, and Italy and Germany saw growth in the 1980s before the 'shocks' of the early 1990s currency crisis and the incorporation of the former German Democratic Republic respectively. Canada did better than these overall, but growth was concentrated in the period from 1995 onwards, with the median declining for much of the preceding 15 years. For the better performers, growth was also often concentrated in specific sub-periods, interspersed with stagnation or decline. For Australia, most of the growth over the period as a whole was from the mid-1990s, and especially from 2000 to 2007 at the height of its minerals boom. Finland, Norway and Sweden saw sharp declines from 1990 to 1995, when they were hit by financial crises and recession. The UK had sharply contrasting experiences of stagnation in the early 1980s and early 1990s versus strong growth from 1985-1990 and 1995-2007, followed by a decline from 2007 on as the Economic Crisis struck. 
Table 3: Growth in Median Equivalised Household Income in Real Terms by Country, Longest Period Covered from About 1980

\begin{tabular}{l|cc|cc}
\hline Country & $\begin{array}{c}\text { Initial } \\
\text { Year }\end{array}$ & $\begin{array}{c}\text { End } \\
\text { Year }\end{array}$ & $\begin{array}{c}\text { Overall increase } \\
\%\end{array}$ & $\begin{array}{c}\text { Annual average } \\
\text { growth rate \% }\end{array}$ \\
\hline & & & & \\
Australia & 1981 & 2010 & 41.93 & 1.21 \\
Austria & 1994 & 2013 & 15.58 & 0.77 \\
Belgium & 1985 & 2013 & 52.34 & 1.51 \\
Canada & 1980 & 2013 & 20.22 & 0.56 \\
Czech Republic & 1992 & 2013 & 61.12 & 2.30 \\
Denmark & 1987 & 2013 & 17.84 & 0.63 \\
Estonia & 2000 & 2013 & 105.97 & 5.72 \\
Finland & 1987 & 2013 & 38.01 & 1.25 \\
France & 1978 & 2010 & 31.27 & 0.85 \\
Germany & 1984 & 2013 & 14.11 & 0.46 \\
Greece & 1986 & 2013 & -13.90 & -0.55 \\
Hungary & 1991 & 2012 & -4.44 & -0.22 \\
Iceland & 2004 & 2010 & -1.10 & -0.18 \\
Ireland & 1987 & 2010 & 105.76 & 3.19 \\
Israel & 1986 & 2012 & 55.27 & 1.71 \\
Italy & 1986 & 2014 & 9.53 & 0.33 \\
Japan & 1985 & 2012 & 0.31 & 0.01 \\
Luxembourg & 1985 & 2013 & 80.34 & 2.13 \\
Netherlands & 1977 & 2014 & 32.17 & 0.76 \\
New Zealand & 1985 & 2012 & 23.78 & 0.79 \\
Norway & 1979 & 2013 & 125.24 & 2.42 \\
Poland & 1992 & 2013 & 32.91 & 1.36 \\
Portugal & 2004 & 2013 & -4.62 & -0.52 \\
Slovak Republic & 1992 & 2013 & 45.36 & 1.80 \\
Slovenia & 1997 & 2012 & 27.36 & 1.63 \\
South Korea & 2006 & 2014 & 13.92 & 1.64 \\
Spain & 1980 & 2013 & 64.99 & 1.76 \\
Sweden & 1983 & 2013 & 69.01 & 0.97 \\
Switzerland & 2000 & 2013 & 13.32 & 1.56 \\
United Kingdom & 1979 & 2013 & 69.47 & 0.32 \\
United States & 1979 & 2013 & 11.66 & \\
\hline Average & & & & \\
\hline & & & & \\
Sound & & & \\
\hline
\end{tabular}

Source: LIS except OECD for Belgium (from 2004), Canada, Greece, Japan, Netherlands, New Zealand, Portugal, South Korea, and Sweden

That Crisis and Great Recession was a profound macroeconomic shock for the rich countries as a whole, but its effects on household incomes varied widely across countries. The median fell between 2007 to 2010 in about half the countries covered, but the scale of the decline and subsequent trajectory of the median differed between them. Some saw the accumulated growth 
in median incomes over previous decades wiped out, and in others median incomes returned only slowly and haltingly to their pre-Crisis levels, representing a lost decade of income growth. Ireland and Spain had experienced very rapid growth in the years up to the Crisis, so even with the sharp falls it produced they still registered a substantial increase in the median over the whole period. For Greece, by contrast, the scale of the declines both in the initial stages of the Crisis and especially from 2010 onwards were more than enough to offset the substantial growth also seen there from the mid-1990s; this decline was on a much larger scale than any other OECD country.

The extent of this variation in growth over time means that the ranking of countries in terms of median income growth is quite sensitive to the period examined - which itself is affected by the availability of data. To illustrate the point, Australia and Canada would have been regarded as very poor performers indeed, as bad or worse than the USA, if one was looking back from 1995 at the preceding 15 years. For the UK, even having the starting-point in the late 1970s versus mid-1980s would make a considerable difference. It is not possible to have a common starting-point across countries for the analysis here due to data availability, but even if one could that would not address the underlying issue that countries do not share a common pattern of variation over time, and any starting point may be a low point for one country and a peak for another. This also applies to comparisons focused simply on economic growth and macroeconomic performance. However, with much longer runs of macroeconomic data available on an annual basis, various smoothing methods can be applied to ameliorate if not eliminate this problem. The occasional nature of the observations available on incomes across the distribution do not allow this to be done here. This has to be kept firmly in view, including in seeking to assess whether one country has a better 'model' for inclusive growth than another.

Despite an increasingly interlinked global economy, countries also faced major differences in the environment in which they operated, influencing - for better or worse - the trajectory of 
living standards. Countries such as Australia, Canada and Norway, and to some extent the UK, benefitted in particular periods from oil, gas or mineral resources not available to others. On the other hand, Germany had to cope with the incorporation of the former East Germany, Japan with its distinctive macroeconomic and demographic challenges, and Italy also with distinctive macroeconomic, public finance and demographic challenges.

The transition countries of eastern and central Europe underwent such a fundamental restructuring of their economies that comparisons of performance between the countries in this group may be more illuminating than between them and other OECD countries. There were dramatic differences among them in growth performance as it affected middle-income households. At one extreme, Poland and even more so the Czech Republic registered very substantial growth in median income since the early 1990s. At the other end of the spectrum, Hungary saw real incomes at the middle being lower in 2012 than they were two decades earlier. Differences in the time-period covered by the data for other transition countries make it more difficult to assess the implications of the observed growth rates for them, which also varied widely. Teasing out why such profound differences emerged among the countries facing this highly distinctive challenge is a very important topic for research.

It is also relevant that some of the countries seeing relatively little growth in median incomes over the period from the early/mid-1980s had already achieved high levels of income by that point. Conversely, some of the fastest-growing countries started from much lower levels in the early-mid 1980s and were catching up. Comparison of median income levels expressed in Purchasing Power Parity terms for the early/mid-1980s shows that the US was highest by a considerable margin, with Canada, Germany and Japan also at comparatively high levels. The subsequent increase in the median in \$PPP terms was particularly high in some countries that had relatively low levels at the outset, such as Ireland and Spain, but also in Luxembourg and Norway that started with intermediate levels. The average annual increase in the median in the 
USA was among the lowest seen (though not as low as Japan), much lower than in other countries that had relatively high initial income levels. This meant that by 2010 or 2013 Luxembourg and Norway had higher levels for the median than the USA, and Australia, Canada, Denmark, Finland, Iceland and the Netherlands were much closer to it. The UK, despite achieving relatively strong increases and narrowing the gap, remained further behind the US and below the levels reached in Germany or France.

When the evolution of real disposable income at the median for the entire distribution is compared with that for working-age households only, Table 4 shows that the general perception that older households have done relatively well in recent years finds some support, with the working-age median lagging behind in about half the countries. However, focusing on working-age households has little impact on how most countries ranked in terms of median income growth over decades. (The divergence over shorter periods, in particular 5-year subperiods, was much greater). 
Table 4: Growth in Median Equivalised Household Income for Entire Sample versus Working-Age Households Only, Longest Period Covered from about 1980

\begin{tabular}{|c|c|c|c|c|}
\hline Country & $\begin{array}{c}\text { Average } \\
\text { Annual } \\
\text { Growth All }\end{array}$ & $\begin{array}{c}\text { Average Annual } \\
\text { Growth Working } \\
\text { Age }\end{array}$ & Difference & $\begin{array}{l}\text { Rank by Working } \\
\text { Age Growth (All) }\end{array}$ \\
\hline & $\%$ & $\%$ & & \\
\hline Australia & 1.21 & 1.26 & 0.05 & $16(16)$ \\
\hline Austria & 0.77 & 0.77 & 0.00 & $19(20)$ \\
\hline Belgium & 1.51 & 1.70 & 0.18 & $10(13)$ \\
\hline Canada & 0.56 & 0.50 & -0.06 & $24(23)$ \\
\hline Czech Rep & 2.30 & 2.39 & 0.10 & $3(4)$ \\
\hline Denmark & 0.63 & 0.64 & 0.00 & $22(22)$ \\
\hline Estonia & 5.72 & 6.20 & 0.48 & $1(1)$ \\
\hline Finland & 1.25 & 1.35 & 0.10 & $14(15)$ \\
\hline France & 0.85 & 0.81 & -0.04 & $18(18)$ \\
\hline Germany & 0.46 & 0.53 & 0.07 & $23(24)$ \\
\hline Greece & -0.55 & -0.64 & -0.09 & $30(31)$ \\
\hline Hungary & -0.22 & -0.38 & -0.17 & $29(29)$ \\
\hline Iceland & -0.18 & -0.34 & -0.15 & $28(28)$ \\
\hline Ireland & 3.19 & 3.23 & 0.05 & $2(2)$ \\
\hline Israel & 1.71 & 1.64 & -0.07 & $11(8)$ \\
\hline Italy & 0.33 & 0.23 & -0.09 & $26(25)$ \\
\hline Japan & 0.01 & 0.22 & 0.21 & $27(27)$ \\
\hline Luxembourg & 2.13 & 2.00 & -0.13 & $5(5)$ \\
\hline Netherlands & 0.76 & 0.73 & -0.03 & $21(21)$ \\
\hline New Zealand & 0.79 & 0.77 & -0.02 & 20 (19) \\
\hline Norway & 2.42 & 2.38 & -0.04 & $4(3)$ \\
\hline Poland & 1.36 & 1.34 & -0.02 & $15(14)$ \\
\hline Portugal & -0.52 & -0.95 & -0.43 & $31(30)$ \\
\hline Slovak Rep & 1.80 & 1.86 & 0.06 & $7(6)$ \\
\hline Slovenia & 1.63 & 1.76 & 0.13 & $8(10)$ \\
\hline South Korea & 1.64 & 1.88 & 0.24 & $6(9)$ \\
\hline Spain & 1.53 & 1.43 & -0.10 & $13(12)$ \\
\hline Sweden & 1.76 & 1.75 & -0.02 & $9(7)$ \\
\hline Switzerland & 0.97 & 0.97 & 0.01 & $17(17)$ \\
\hline UK & 1.56 & 1.49 & -0.08 & $12(11)$ \\
\hline USA & 0.32 & 0.27 & -0.05 & $25(26)$ \\
\hline Average & 1.13 & 1.13 & 0.00 & \\
\hline
\end{tabular}

Source: LIS except OECD for Belgium (from 2004), Canada, Greece, Japan, Netherlands, New Zealand, Portugal, South Korea and Sweden.

Focusing then on the twenty-one non-transition countries for which data was available going back at least to the mid-1990s, the following broad groupings in terms of performance in 
generating sustained real income growth for middle and lower-middle working-age households can be distinguished:

- three countries which saw exceptionally high growth, of $2 \%$ per year or above on average, namely Ireland, Norway and Luxembourg;

- another three countries which saw growth lower than that but still comfortably above the average, in the range $1.5 \%-1.9 \%$ per year, namely Belgium, Israel and Sweden;

- four countries that generated growth that was more modest but still above average, in the range $1.25 \%-1.5 \%$, namely the UK, Finland, Spain and Australia;

- seven countries that saw average growth markedly below average in the range $0.5-0.8 \%$ per year, comprising France, Austria, New Zealand, Netherlands, Denmark, Germany and Canada;

- three countries with very modest growth indeed, of only $0.2-0.27 \%$ per annum on average, namely USA, Italy and Japan;

- and finally, with a decline in the median over the period as a whole, there is Greece.

The USA is not the only rich country to have seen little growth in the real value of household incomes around and below the middle in recent decades, but as we have seen only a few others have done as poorly. A grand narrative framed centrally around the US case in these terms is thus misleading if applied to the OECD more generally. Some countries have been much more successful than others in generating inclusive growth over a twenty or thirty-year period, and many have seen periods of growth interspersed with stagnation. The variation in country experiences over time also serves to highlight the importance not just of context and dynamics but also of institutions and policies.

As well as the way their real incomes evolved, other ways of capturing a 'squeezed middle' been advanced in the literature can also be discussed briefly here (for more details see Nolan and Thewissen, (2018a). One is to look at the share of disposable income going to the broadly- 
defined 'middle' of the income distribution; this declined in the years up to 2007 in half the countries examined. This decline was particularly marked in the UK and the USA, where the middle three-fifths of the working age population saw their share of total income fall by more than 4 percentage points. A substantial increase in the Gini coefficient was generally, though not always, accompanied by a declining share going to the middle, so rising inequality has generally been bad for the broad middle in terms of its share of total income. Patterns through the Crisis itself were more varied: the income share of the middle $60 \%$ did not continue to decline in most of the countries where it had been falling (though Sweden, the UK and USA were exceptions), but it did start to fall in a number of countries where it had previously been stable or increasing.

Another concern about the middle is that the size of the group itself has been squeezed, often discussed in terms of a middle-class lifestyle becoming harder to sustain people and people 'falling out' of the middle class. 'Middle class' is a term which is open to a wide range of different interpretation, meaning different things not only to economists versus sociologists but also in everyday usage from one country to another. It is nonetheless of interest to look at what has been happening to the proportion of households who can be thought of as 'in the middle' in purely income terms. The proportion of households with incomes between $75 \%$ and $167 \%$ of the median was found to have declined in most of the countries examined, up to the economic crisis. Countries with particularly marked falls include Australia, Canada, Czech Republic, Finland, Iceland, Israel, Poland, Slovak Republic, and especially Sweden, the UK and the USA. While rising inequality may not always go together with a shrinking of the size of the middle framed in this fashion, it has very often done so in practice in the decades up to the Great Recession.

\section{Inequality and Middle Income Growth}


The notion that rising income inequality may be at least partly to blame for stagnation in real incomes and living standards for ordinary working families plays a central role in the 'grand narratives' in circulation about recent economic and political instability. This represents a recent departure from the more traditional framing of the relationship between equality and economic efficiency as 'the Great Trade-Off'. Now, instead, the ways in which inequality may negatively impact on middle income growth are to the fore, especially in the US, as emphasized in the introduction. Recent aggregate-level comparative studies from the IMF and the OECD suggesting that an increase in the share of total income going to the top drags down growth, and that the scale of redistribution through direct taxes and transfers does does not damage it, have received a great deal of attention. While empirical studies are also now emerging on the specific channels through which inequality may affect growth, these are often for just one or two countries, with the US being the primary focus. Even effects that are robustly identified in a US context may not apply elsewhere, and much research remains to be done on these causal channels.

Here, we put the way the Gini coefficient and top income shares evolved as presented in Section 3 alongside the trends in the median as described in Section 4. Descriptively, one can see that, once again, there have been widely varying experiences. Figure 1 plots the average real growth in the median for each country from Section 4 against the change in the Gini over the entire period covered by the data for the country in question. This brings out the wide spread in the scatterplot; if anything, average growth in the median in marginally higher where the increase in the Gini has been greater, but there is little sign of a clear relationship between the two. 
Figure 1: Annual Average Growth in Median Income Versus Change in Inequality, OECD Countries, Longest Period Covered

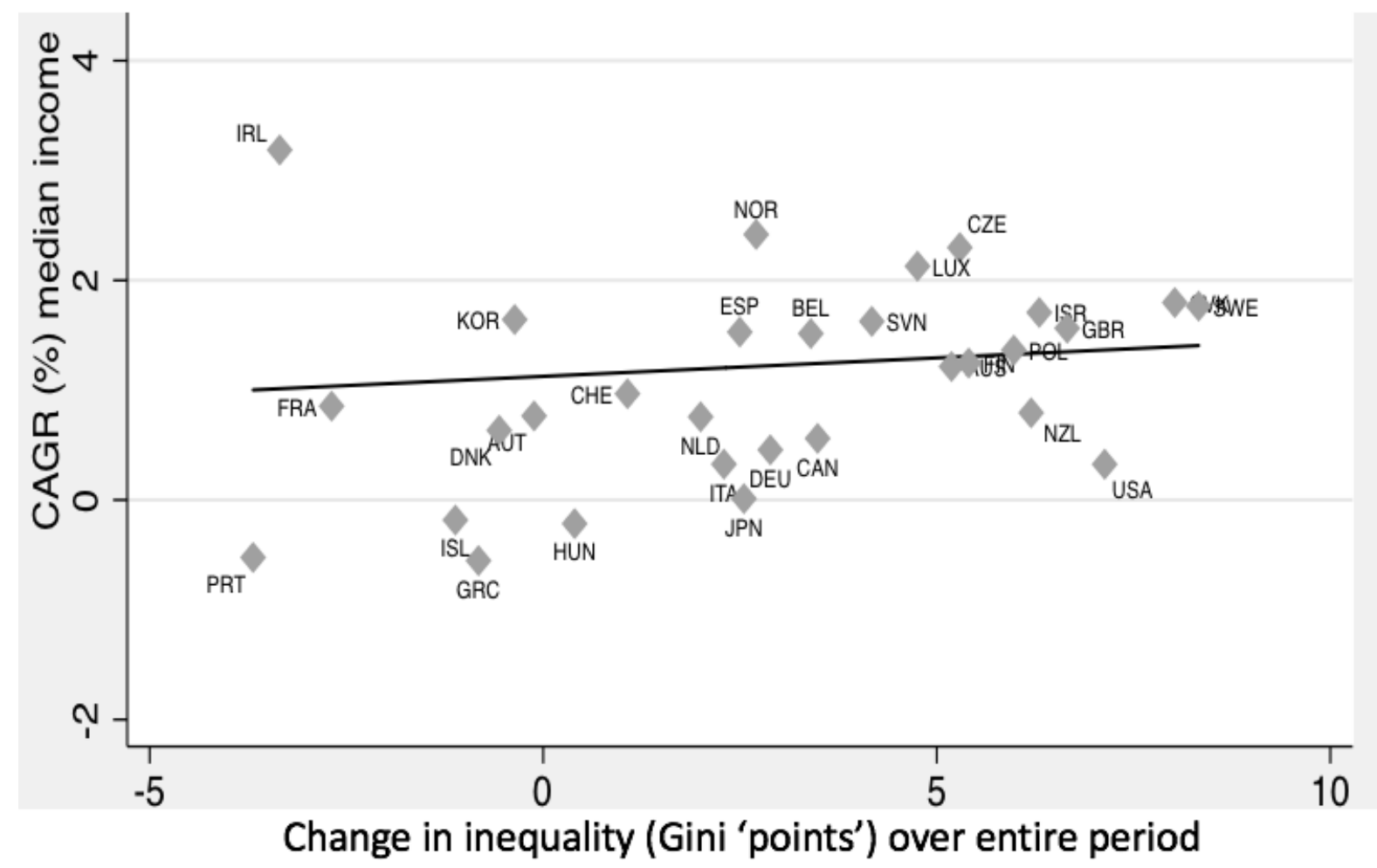

Focusing on the sub-periods distinguished in our data ${ }^{3}$, Figure 2 plots the annual average change in the median against the average change in the Gini coefficient in the same sub-period. This again does not suggest a strong relationship between the two (though the slope of a simple linear regression line would now be downwards). Simply deriving the correlation between them, median income growth is negatively correlated with the change in the Gini across all these observation points, but that correlation is very modest at -0.13 . There are countries and sub-periods where the median stagnated and inequality rose rapidly, but also ones where increasing inequality accompanied rapid growth in the median, and others where the median rose only modestly while inequality was stable.

\footnotetext{
${ }^{3}$ These approximate to $1980-85,1985-90,1990-95,1995-2000,2000-2007,2007-2010$, and 20102013, as closely as the available data for a given country permit.
} 
Figure 2: Annual Average Growth in Median Income versus Change in Inequality in Same Sub-Period, OECD Countries

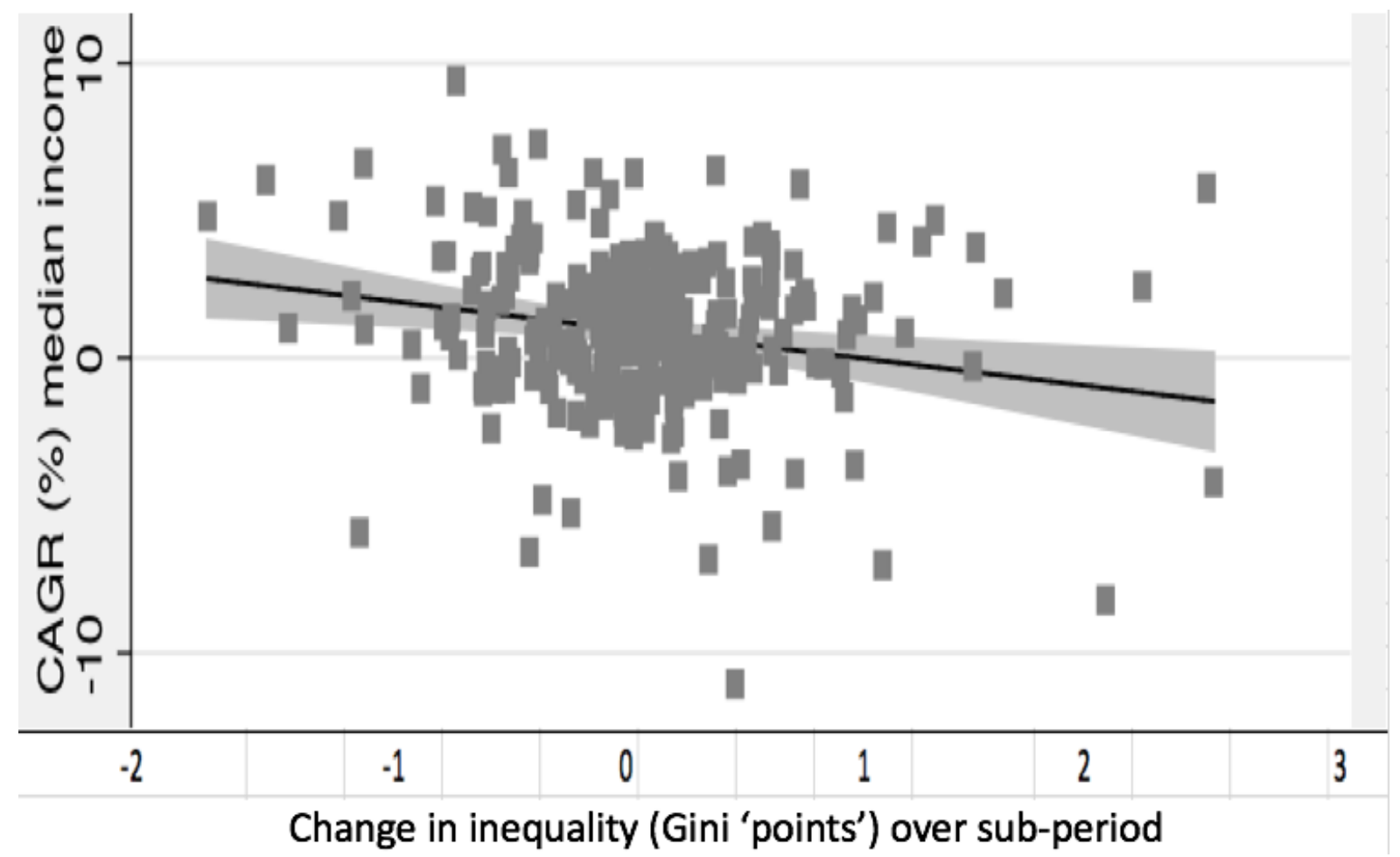

Thewissen et al (2018) probe this relationship in more depth, estimating a variety of statistical models with the change in median income in the sub-period in question as the dependent variable, and explanatory variables including the change in the Gini coefficient, the change in the income share of the top $1 \%$, the level of the median and of the Gini in the previous period, and a set of control variables including the average years of schooling of the working-age population and the dependency rate. A negative and statistically significant association between median income growth and the contemporaneous change in the Gini coefficient was found, but this accounted for only a small proportion of the variation in median income growth. When the rate of GDP growth in the same period (which could itself be influenced by inequality levels and changes) is included this substantially increases the explanatory power of the model, the change in the Gini is still marginally statistically significant, but a substantial part of the variation in income change at the middle remains unexplained. 
These findings can only be suggestive, but they do suggest that neither the previous presumption that high inequality would boost growth nor the "grand narrative" featuring so strongly in current debates that high or rising inequality consistently reduces real income growth for the middle adequately captures the variety of experiences actually observed across the rich countries in recent decades.

\section{GDP Growth and Growth in Middle Incomes}

Growth in national output/income per head as measured in the national accounts, while subject to a variety of critiques, is still the most frequently-used benchmark for assessing macroeconomic performance. How misleading is it as an indicator of how real incomes and living standards evolve for ordinary working families? Table 5 compares the average annual growth in median incomes we derived as described earlier with the average annual growth in national output/income per head by country, calculated over the years covered by our survey data for each country, together with each country's ranking on those outcomes from highest to lowest. This brings out first that growth in the median lagged considerably behind that in real Gross National Income (GNI) per head in most countries, though there were exceptions such as Norway, Luxembourg and Estonia. 
Table 5: Average Annual Growth in Real Median Equivalised Household Income and GNI per capita by Country, Longest Period Covered from About 1980

\begin{tabular}{|c|c|c|c|c|}
\hline & $\begin{array}{l}\text { Average Annual } \\
\text { Growth in } \\
\text { Median }(\%)\end{array}$ & $\begin{array}{l}\text { Rank by } \\
\text { Growth in } \\
\text { Median }\end{array}$ & $\begin{array}{c}\text { Average Annual } \\
\text { Growth in GNI } \\
(\%)\end{array}$ & $\begin{array}{l}\text { Rank by } \\
\text { Growth in } \\
\text { GNI }\end{array}$ \\
\hline Estonia & 5.72 & 1 & 4.11 & 2 \\
\hline Ireland & 3.19 & 2 & 3.53 & 4 \\
\hline Norway & 2.42 & 3 & 2.04 & 8 \\
\hline Czech Republic & 2.30 & 4 & 2.01 & 9 \\
\hline Luxembourg & 2.13 & 5 & 1.50 & 23 \\
\hline Slovak Republic & 1.80 & 6 & 3.94 & 3 \\
\hline Sweden & 1.76 & 7 & 1.78 & 11 \\
\hline Israel & 1.71 & 8 & 2.21 & 6 \\
\hline South Korea & 1.64 & 9 & 3.15 & 5 \\
\hline Slovenia & 1.63 & 10 & 2.14 & 7 \\
\hline United Kingdom & 1.56 & 11 & 1.52 & 21 \\
\hline Spain & 1.53 & 12 & 1.59 & 17 \\
\hline Belgium & 1.51 & 13 & 1.62 & 16 \\
\hline Poland & 1.36 & 14 & 4.40 & 1 \\
\hline Finland & 1.25 & 15 & 1.62 & 15 \\
\hline Australia & 1.21 & 16 & 1.72 & 13 \\
\hline Switzerland & 0.97 & 17 & 0.48 & 29 \\
\hline France & 0.85 & 18 & 1.51 & 22 \\
\hline New Zealand & 0.79 & 19 & 1.28 & 26 \\
\hline Austria & 0.77 & 20 & 1.52 & 20 \\
\hline Netherlands & 0.76 & 21 & 1.53 & 19 \\
\hline Denmark & 0.63 & 22 & 1.32 & 25 \\
\hline Canada & 0.56 & 23 & 1.36 & 24 \\
\hline Germany & 0.46 & 24 & 1.67 & 14 \\
\hline Italy & 0.33 & 25 & 0.87 & 27 \\
\hline United States & 0.32 & 26 & 1.73 & 12 \\
\hline Japan & 0.01 & 27 & 1.58 & 18 \\
\hline Iceland & -0.18 & 28 & -2.21 & 31 \\
\hline Hungary & -0.22 & 29 & 1.82 & 10 \\
\hline Portugal & -0.52 & 30 & -0.34 & 30 \\
\hline Greece & -0.55 & 31 & 0.52 & 28 \\
\hline
\end{tabular}

Secondly, the gap between the two is not consistent, so two measures give a rather different impression of how countries compare. The USA in particular would rank $12^{\text {th }}$. out of these 31 countries in terms of average GNI growth, compared with $26^{\text {th }}$. by median income growth. 
Germany, Japan, Hungary and Poland also rank considerably higher by average GNI growth per head.

The relationship between average annual growth in the median versus in GNI is illustrated in Figure 3. This, and the simple fitted regression line it includes, underlines that growth in the median has lagged behind that in GNI on average across these countries, with only four-fifths of the increase in GNI reflected in median income growth on average. However, it also brings out that there is considerable variation in the proportion of GNI growth that is transmitted to the median. This is even more pronounced if one looks at the relationship within sub-periods rather than across the period as a whole, where the ability of GNI growth to 'predict' growth in the median is considerably weaker.

Figure 3: Annual Average Growth in the Median vs GNI, Longest Period Covered for Each Country

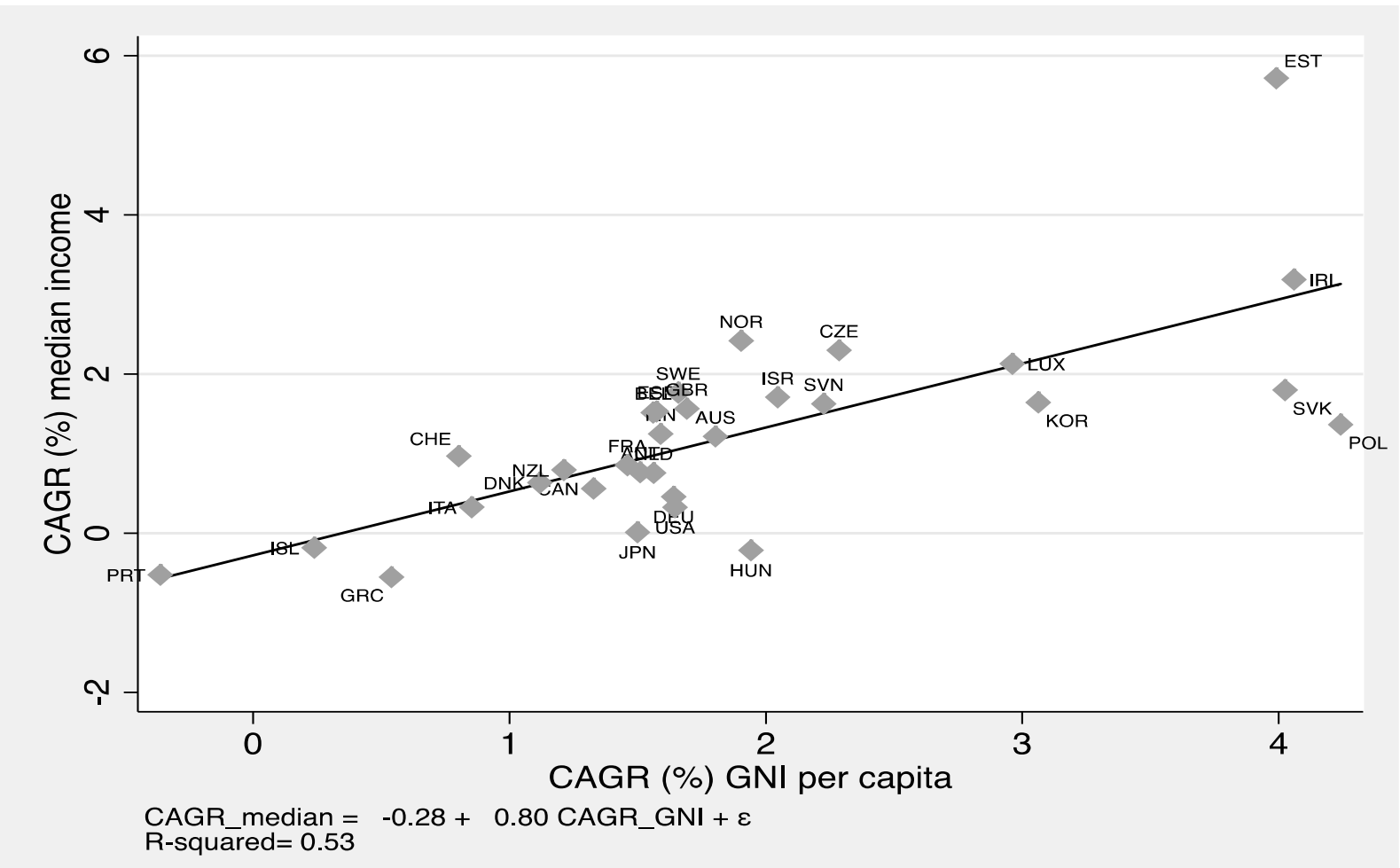


One reason why a country could see growth in the median lag behind national income per capita would be if the benefits from the latter are concentrated towards the top rather than the middle of the distribution: increasing inequality, could be key. However, the model estimates in Thewissen et al (2018) described in the previous section, with changes in inequality included in the model, suggest that on average only about three-quarters of the increase in national income in a given sub-period is reflected in real income growth at the median. It is clear that a variety of other factors, in terms of both underlying dynamics and measurement-related issues, also contribute to the divergence.

Nolan, Roser and Thewissen (2018) investigate the complexities of this relationship, distinguishing a number of distinct contributory factors. Increasing income inequality was found to play a substantial role in the case of the US, as well as Canada, but even there was by no means the main factor at work. The fact that nominal growth in national income is generally deflated by the change in producer prices whereas household incomes are deflated by the change in consumer prices was seen to be important in the case of the US but was not as important in most other countries. The distinction between Gross Domestic Product and Gross National Income, where the latter includes only flows relating to residents in the country in question, was important for only a few countries with exceptionally large net factor outflow, such as Ireland and Luxembourg. The most important factor on average across countries and the most consistent contributor to the divergence has received very little attention in this context, or indeed in thinking about the evolution of household living standards more generally, namely declining household size. With average household size falling over time in most countries, in effect fewer of the potential economies of scale from living together are being exploited.

Among the other factors at work, GNI refers to the entire economy, with a significant proportion of national income flowing to the corporate rather than the household sector. Honing 
in on the household sector in the national accounts (which is only possible for many countries on a hamonised countries since the mid-1990s), certain income sources such as imputed rent, retained profits, or in-kind benefits are taken into account in the national accounts but are (often) not reported in household surveys. Finally, surveys may not reliably capture the income from different sources that they aim to cover, while national accounts aggregates are also measured imperfectly. Nolan, Roser and Thewissen (2018) found that these factors also contributed to the observed GDP-median gap for some countries, but mostly less than other factors. The scale of the divergence and the factors contributing to it, including the impaxct of rising inequality, were distinctive to the US, serving again to underline how cautious one must be about generalising from the experience of a single country, no matter how important.

\section{Inequality, Growth and Real Incomes of the Poor}

So far we have been focused on real income growth around the middle of the distribution, in keeping with the widespread concern about the 'squeezed middle'. We now turn our attention to those in the lower parts of the income distribution, to see whether they shared in the experiences of the middle, or generally did better or worse in terms of real income growth. We employ the trajectory of the income level cutting off the bottom $10 \%$ from the rest of the distribution, $\mathrm{P}_{10}$, as a crude but informative indicator of how the real incomes of the poor have evolved. It will not capture the mean or even the median income of the poor, since where $\mathrm{P}_{10}$ lies in the distribution among the poor will depend on the scale of poverty, how many are below the poverty threshold, and that in turn will depend on how poverty is being conceptualized and measured. However, it can provide a sense of how real incomes in the relevant part of the income distribution have evolved, as well as how that relates to incomes around the middle. Table 6 compares average annual growth in the median for working-age households with the corresponding growth rates at the $\mathrm{P}_{10}$ and (for comparative purposes) $\mathrm{P}_{30}$ cut-offs over the longest observation period available for each country. The patterns vary across countries, but 
there are some common if not universal features. First comparing the average growth rates for the median and $\mathrm{P}_{30}$ across all the countries, the latter grew by $0.2 \%$ less on average. Looking country by country, this differential was also almost always to the disadvantage of the lower percentile - only in four countries did it grow faster than the median, and then only marginally. However, for most countries the growth in the median, down-scaled by about $20 \%$, would be a reasonably good predictor of growth in $\mathrm{P}_{30}$.

Table 6: Real Growth in Median Equivalised Household Income versus $P_{10}$ and $P_{30}$ for Working Age Households by Country, Longest Period Covered from about 1980

\begin{tabular}{|c|c|c|c|}
\hline & Median & $P_{30}$ & $\mathrm{P}_{10}$ \\
\hline & $\%$ & $\%$ & $\%$ \\
\hline Australia & 1.26 & 1.14 & 1.06 \\
\hline Austria & 0.77 & 0.71 & 0.84 \\
\hline Belgium & 1.70 & 1.68 & 0.94 \\
\hline Canada & 0.50 & 0.38 & 0.37 \\
\hline Czech Rep & 2.39 & 2.16 & 1.41 \\
\hline Denmark & 0.64 & 0.53 & 0.61 \\
\hline Estonia & 6.20 & 6.01 & 4.92 \\
\hline Finland & 1.35 & 1.17 & 0.77 \\
\hline France & 0.81 & 0.84 & 0.59 \\
\hline Germany & 0.53 & 0.36 & 0.11 \\
\hline Greece & -0.64 & -0.81 & -1.32 \\
\hline Hungary & -0.38 & -0.62 & -1.06 \\
\hline Iceland & -0.34 & -0.67 & -0.35 \\
\hline Ireland & 3.23 & 3.33 & 3.34 \\
\hline Israel & 1.64 & 1.28 & 0.45 \\
\hline Italy & 0.23 & 0.01 & -0.84 \\
\hline Japan & 0.22 & -0.07 & -0.69 \\
\hline Luxembourg & 2.00 & 1.80 & 1.45 \\
\hline Netherlands & 0.73 & 0.61 & 0.12 \\
\hline New Zealand & 0.77 & 0.54 & 0.27 \\
\hline Norway & 2.38 & 2.28 & 1.93 \\
\hline Poland & 1.34 & 1.05 & 0.38 \\
\hline Portugal & -0.95 & -1.10 & -2.05 \\
\hline Slovak Rep & 1.86 & 1.46 & 0.39 \\
\hline Slovenia & 1.76 & 1.34 & 0.63 \\
\hline South Korea & 1.88 & 2.23 & 2.65 \\
\hline Spain & 1.43 & 1.14 & 0.49 \\
\hline Sweden & 1.75 & 1.39 & 0.67 \\
\hline Switzerland & 0.97 & 0.85 & 0.89 \\
\hline UK & 1.49 & 1.27 & 1.22 \\
\hline USA & 0.27 & 0.01 & -0.08 \\
\hline Average & 1.20 & 1.01 & 0.59 \\
\hline
\end{tabular}


Source: LIS except OECD for Belgium (2001-2013), Canada, Greece, Japan, Netherlands, New Zealand, Portugal, South Korea and Sweden.

The divergence between the median and $\mathrm{P}_{10}$ is considerably larger, though, at $0.6 \%$ on average; this means that the average annual growth at this percentile across all the countries/periods covered was only half that of the median. Strikingly, in a substantial minority of countries $\mathrm{P}_{10}$ grew by as much as a full percentage point per year less than the median on average. In Sweden the median grew $1.8 \%$ per year on average while $\mathrm{P}_{10}$ grew by only $0.7 \%$; in Poland the corresponding figures were $1.3 \%$ and $0.4 \%$. In Italy, while the median grew by a very modest $0.2 \%$ on average, $\mathrm{P}_{10}$ actually declined by about $0.8 \%$ per year. In the US case, while the median only grew by $0.3 \%$ per year on average, remarkably $\mathrm{P}_{10}$ was no higher in 2013 than it had been in 1980. As well as average growth rates across the full periods for which we have data, the trajectory of the different percentiles over time varies across sub-periods, with wider or narrower gaps between them being seen.

The fact that growth in lower incomes generally lagged behind the middle is an important aspect of rising inequality, in danger of being obscured by the attention paid to what has been going on at the top. This can be brought out by looking at the ratio of the $90^{\text {th }}$. to the $10^{\text {th }}$. percentile, a commonly-used summary inequality measure where one can readily see the role being played by developments towards the bottom as well as the top. It will by construction not be affected by what is happening at the very top or bottom, unlike the Gini coefficient, but captures what is happening across the broad mass of the income distribution. Table 7 first shows this ratio and how it changed over the longest period for which we have data for each country. It again shows inequality rising in most though not all of the countries covered. Countries where the Gini rose markedly general also saw $\mathrm{P}_{90} / \mathrm{P}_{10}$ rise substantially, though there is by no means a perfect alignment between the two measures (for example, Japan saw a 
sharp rise in this ratio but only a quite limited increase in the Gini). Israel saw the largest increase, from 4.1 to 6.4 .

Table 7: Percentile Ratios by Country, Longest Period Covered from About 1980, Working-age Population

\begin{tabular}{|c|c|c|c|c|c|}
\hline Country & $\begin{array}{c}\mathrm{P}_{90} / \mathrm{P}_{10} \\
\text { Initial Value }\end{array}$ & $\begin{array}{c}\mathrm{P}_{90} / \mathrm{P}_{10} \text { End } \\
\text { Value }\end{array}$ & $\begin{array}{c}\text { Change in } \\
\mathrm{P}_{90} / \mathrm{P}_{10}\end{array}$ & $\begin{array}{c}\text { Change in } \\
\mathrm{P}_{50} / \mathrm{P}_{10}\end{array}$ & $\begin{array}{c}\text { Change in } \\
\mathrm{P}_{0} / \mathrm{P}_{50}\end{array}$ \\
\hline Australia & 3.83 & 4.44 & 0.60 & 0.12 & 0.17 \\
\hline Austria & 3.44 & 3.38 & -0.06 & -0.03 & -0.01 \\
\hline Belgium & 2.72 & 3.22 & 0.51 & 0.23 & 0.07 \\
\hline Canada & 4.01 & 4.64 & 0.63 & 0.10 & 0.19 \\
\hline Czech Republic & 2.28 & 3.19 & 0.91 & 0.34 & 0.22 \\
\hline Denmark & 2.82 & 2.90 & 0.08 & 0.01 & 0.04 \\
\hline Estonia & 5.32 & 5.70 & 0.38 & 0.40 & -0.19 \\
\hline Finland & 2.42 & 3.15 & 0.73 & 0.26 & 0.18 \\
\hline France & 3.61 & 3.74 & 0.13 & 0.14 & -0.06 \\
\hline Germany & 3.08 & 3.77 & 0.69 & 0.24 & 0.14 \\
\hline Greece & 4.94 & 5.65 & 0.71 & 0.46 & -0.11 \\
\hline Hungary & 3.35 & 4.05 & 0.70 & 0.29 & 0.09 \\
\hline Iceland & 2.90 & 2.81 & -0.09 & 0.00 & -0.05 \\
\hline Ireland & 4.31 & 3.83 & -0.48 & -0.05 & -0.18 \\
\hline Israel & 4.14 & 6.36 & 2.22 & 0.74 & 0.26 \\
\hline Italy & 3.94 & 5.24 & 1.31 & 0.71 & -0.03 \\
\hline Japan & 4.00 & 5.27 & 1.27 & 0.60 & 0.05 \\
\hline Luxembourg & 2.86 & 3.61 & 0.75 & 0.27 & 0.14 \\
\hline Netherlands & 2.87 & 3.55 & 0.67 & 0.41 & -0.02 \\
\hline New Zealand & 3.43 & 4.35 & 0.92 & 0.27 & 0.20 \\
\hline Norway & 2.56 & 3.13 & 0.56 & 0.27 & 0.08 \\
\hline Poland & 3.16 & 4.21 & 1.05 & 0.39 & 0.16 \\
\hline Portugal & 5.39 & 5.34 & -0.04 & 0.24 & -0.24 \\
\hline Slovak Republic & 2.21 & 3.59 & 1.39 & 0.53 & 0.30 \\
\hline Slovenia & 2.76 & 3.54 & 0.78 & 0.32 & 0.14 \\
\hline Spain & 4.28 & 6.17 & 1.88 & 0.76 & 0.12 \\
\hline Sweden & 2.34 & 3.56 & 1.22 & 0.58 & 0.16 \\
\hline Switzerland & 3.21 & 3.33 & 0.11 & 0.02 & 0.04 \\
\hline United Kingdom & 3.18 & 4.20 & 1.02 & 0.18 & 0.36 \\
\hline United States & 4.40 & 5.97 & 1.57 & 0.31 & 0.38 \\
\hline Average & 3.48 & 4.18 & 0.70 & 0.29 & 0.08 \\
\hline
\end{tabular}

Source: LIS except OECD for Canada, Greece, Japan, Netherlands, New Zealand, Portugal, and Sweden, and for Belgium from 2004. 
We can then look behind the change in the $\mathrm{P}_{90} / \mathrm{P}_{10}$ ratio at what underlies it, in terms of the changing relationship between the middle of the distribution and those towards the bottom versus the top, with Table 7 also showing how the ratios of the median to the tenth percentile and of $\mathrm{P}_{90}$ to the median changed. As we have seen, the tenth percentile lagged behind the median in most countries, reflected in an increase in the ratio of the median to $\mathrm{P}_{10}$. The countries where the gap between them widened most substantially were Estonia, Greece, Israel, Italy, Japan, Slovak Republic, Spain and Sweden. That gap also widened in the US, but by not much more than the average increase across all the countries. The ratio of the $90^{\text {th }}$. percentile to the median in fact rose less consistently than $\mathrm{P}_{50} / \mathrm{P}_{10}$. It did however rise particularly sharply in the UK and the USA, the countries where the focus on the top has been most prominent in debates about rising inequality. (This has mostly focused on what has been happening at the very top

of the distribution rather than around the $90^{\text {th }}$. percentile; capturing the very top entails drawing on other sources than household surveys, as discussed earlier.) Elsewhere, what has been happening in the bottom half may be as important in driving inequality upwards, at least insofar as survey data capture it. In the case of Sweden, for example, the bottom falling away from the middle made a considerably greater impact on the overall change in $\mathrm{P}_{90} / \mathrm{P}_{10}$. For Greece, that was responsible for all the increase in $\mathrm{P}_{90} / \mathrm{P}_{10}$, with $\mathrm{P}_{90} / \mathrm{P}_{50}$ actually declining.

\section{Sources of Growth for Middle and Lower Incomes and Their Relationship with GDP Growth}

In seeking to understand the drivers of income growth for ordinary working households and for the poor, it is helpful to identify the main sources of income accruing to households at different points in the income distribution and assess the role each has played in household income growth over time around the middle and towards the bottom. For this purpose we draw initially from findings of analysis based on data from the OECD's Income Distribution Statistics covering 26 countries as reported in Nolan, Thewissen and Lazzati (2018). 
For the fifth decile, this showed that, on average across these countries around 2011/12, the wage of the main earner made up more than half of total disposable income, with the wage income of the spouse contributed another quarter. Around one-fifth of total income came from transfers, but these household paid slightly more in direct taxes/social contributions than they received in such transfers on average. (Before the onset of the Great Recession, the share of income coming from wages was about 2 percentage points higher and that of transfers correspondingly smaller.) What was striking in these findings, though, was the extent of variation across countries in the make-up of income around the middle. The wage of the main earner accounted for $40 \%$ or less in some countries, versus $70 \%$ or more in others; the earnings of the spouse/partner ranged from as little as $10 \%$ up to as much as $40 \%$ or more; and public transfers represented only $10 \%$ in some countries versus $30 \%$ in others.

This variation was also seen in how these income composition patterns evolved over time for the fifth decile, going as far back for each country as the data permitted. Figure 5 shows average growth incidence curves, where countries are simply pooled as a sample. These bring out that on average, around the middle of the distribution the wages of the main earner were the single most important contributor to overall income growth, closely followed by the earnings of the spouse/partner and by public transfers; other sources were much less important. However, there was a good deal of variation around this average from one country to the next. In some, the wage of the main earner made little or no contribution to growth, or even served to reduce it; it others it was the main driver, and very much more important than the wages of other household members. More commonly, it made some positive contribution alongside the wages of other household members. The net impact on middle income growth of public transfers, once direct taxes and social security contributions are deducted, also varied very widely across countries. Distinguishing those countries that saw reasonably strong growth in middle incomes from those which did much less well in that regard, the wage of the main earner boosted growth 
in the former and pulled it down in the latter, but the earnings of the spouse and other earners also mattered. 


\section{Figure 5: Decomposed Growth Incidence Curves for OECD Countries Pooled}

\section{A/: All available years}
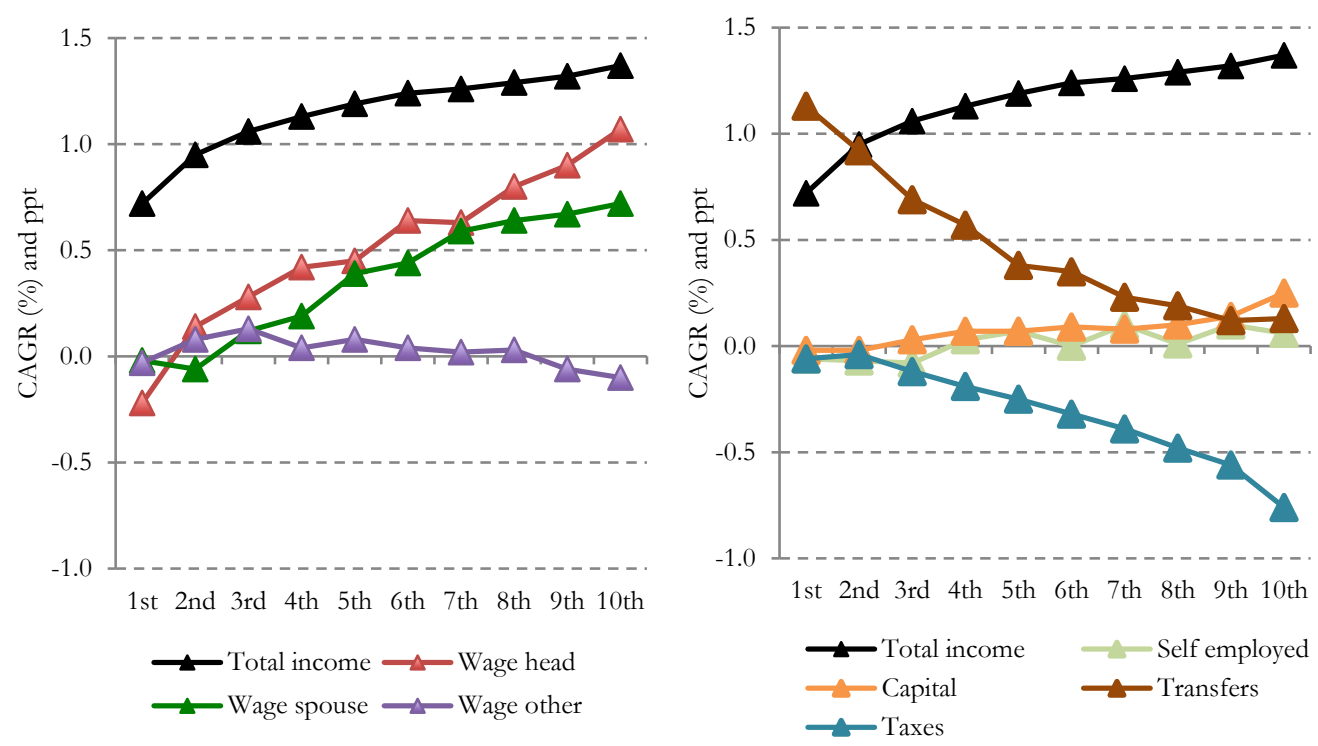

B/: Years Before the Great Recession
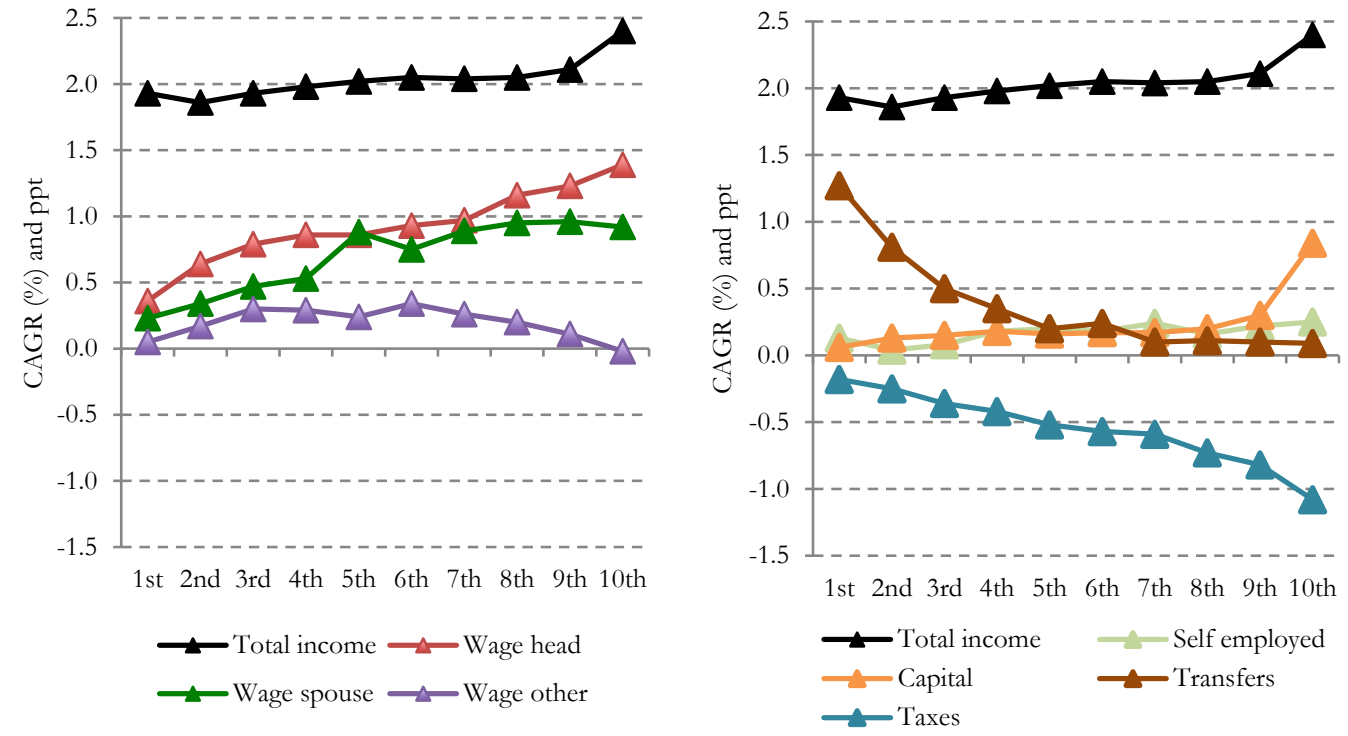

The bottom decile unsurprisingly looks very different to the middle in income composition terns. On average across countries, more than half of its income comes from public transfers, with the wage of the main earner being the other important source. Figure 5 shows that transfers were also key to the income growth seen over time for this part of the distribution, again on average. 


\section{The Implications for Monitoring and Promoting Progress}

The analysis and findings presented here have major implications for how economic progress should be measured and monitored. They reinforce existing concerns about relying on growth in GDP per head to capture living standards in the longer term, or how incomes at and below the middle are faring in the short term. GDP per head will not be a reliable indicator of income change for these households, in the short or long run, due to a variety of factors that themselves vary in significance across countries and over time. Given the difficulty of assessing the likely impact of these factors in 'real time', median income needs to be accorded a central role alongside GDP per capita in both official monitoring of living standards and how they are changing over time, and, as here, in research on inclusive growth.

However, the median for all households may not provide a good guide to what has been happening to working-age households, at least over shorter periods. Given the specific interest in working-age households, it is also important to have income indicators that apply to them. Furthermore, the trajectory of incomes lower down the distribution may well diverge, it would be hazardous to rely on growth in median incomes for the working-age population, or for the population as a whole, as a reliable indicator of income growth for those much lower down the distribution over a relatively short period such as five years, much less from one year to the next. That does not take away from the value of the median in capturing what is happening to incomes around the middle of the distribution and the extent to which economic growth has fed through to those incomes, but it does mean that low incomes and poverty certainly need to be separately monitored and analysed: one cannot assume that growth that transmits to the middle is also going towards the bottom.

This means that placing the median for the entire population alongside GDP (or GNI) per capita as a key indicator, as some have advocated (for example, Atkinson et al., 2015), may be a real advance but not go far enough. If how middle-income working-age families are faring is of 
particular salience, then the income trajectory for such households needs to be captured directly. That will not be a reliable measure of what is happening to the incomes of the poor, though, and thus of inclusive growth more broadly conceived. The 'dashboard' of indicators employed to assess progress and inform policy needs to incorporate measures focused directly both on the middle and towards the bottom, since each is of central societal concern.

Such measures relating to household incomes, as captured for the most part in household surveys can usefully also be set in a broader framework where their relationship to national accounts income aggregates is elaborated, and the distribution of elements missed by surveys and/or not reflected in cash incomes incorporated into the picture. In that context, recent advances towards the development of distributional national accounts, by both the OECD/EU and national statistics offices and by academic researchers in the DINA project are of fundamental importance. However, they should be seen as complements rather than substitutes: tracking and understanding the evolution of household cash incomes remains of central importance, and improving the capacity to measure incomes across the distribution drawing on survey and administrative data is key to doing so reliably.

Turning from monitoring progress to strategies to promote it, we noted at the outset that a 'grand narrative' has emerged in commentary and public debate that sees rising inequality as responsible for long-term stagnation in living standards for 'ordinary working families'; emphasizes the various ways in which the 'middle' in particular is being 'squeezed'; identifies globalization and technological change as key drivers, especially in 'hollowing out' the labour market and driving more and more polarization into a small 'cognitive elite' with secure wellrewarded jobs versus the bulk of the workforce with 'bad jobs'; and sees inequality in wealth rising alongside that in incomes, choking off opportunity for those not coming from advantaged backgrounds. This toxic combination is then held responsible for a wide range of societal and political ills, not least the erosion of solidarity, social trust, and faith in democratic institutions 
and the rise of populism, which — harking back to the 1930s — are seen to threaten the future of democracy.

This is now especially common in debates about the USA, but is often taken to apply across the rich countries much more widely. What the findings presented here bring out, however, is the diversity of rich country experiences in terms of the key elements of this 'story', which should serve as an important corrective to a common narrative. This applies with respect to real income growth around and below the middle; the extent of the increase in income inequality; the degree to which 'the middle' can be taken to have done poorly in relative or absolute terms; the contributors to income growth or its absence; and the scale and nature of the divergence between growth in median incomes versus GDP per head.

This 'grand narrative' undoubtedly captures important aspects of US experience, although not representing the whole story even there, and some parts are certainly salient for other rich countries, and more salient for some than for others. However, their experiences, contexts, and challenges vary to such a degree that no single narrative can do them justice, including this one. Losing sight of this complexity is hazardous in terms of both understanding and responding to those challenges. This applies not only to the economic domain which is the focus here, but also to the political aspects of the narrative. Stagnating wages and rising inequality share some common roots, and many of the policies required to effectively address inequality would also enhance income growth for ordinary households. However, addressing inequality, however desirable, could not be relied upon to produce adequate income growth, nor should the case for tackling inequality be reduced to this instrumental one, pushing concerns about fairness and social justice into the background. While common forces will continue to operate across the rich countries, such as the advance of AI and robotization, the way they play out will continue to depend crucially on the institutions in place and the policies adopted in the country in question. Even what are often debated as 'one size fits all' solutions, 
such as universal basic income, turn out on closer examination to mean very different things depending on the context. While learning from experiences elsewhere, different countries will have to continue to find their own road to salvation.

\section{References}

Aaberge, R., Langorgen, A. and Lindgren, P. (2013). 'The distributional impact of public services in European countries', Eurostat Methodologies and Working Papers 2013 edition, Publications Office of the European Union, Luxembourg.

Atkinson, A.B., Marlier, E. and Guio, A.-C. (2015). 'Monitoring the evolution of income poverty and real incomes over time', CASE Paper 188, Centre for Analysis of Social Exclusion, London School of Economics and Political Science, London.

Atkinson, A.B., Rainwater, L. and Smeeding, T. (1995). Income distribution in OECD countries: The evidence from the Luxembourg Income Study (Paris: Organization for Economic Cooperation and Development).

Boushey, H. (2019). Unbound: How Inequality Constricts Our Economy and What We Can Do about It, Harvard University Press, Cambridge Mass.

Cingano, F. (2014). 'Trends in Income Inequality and its Impact on Economic Growth', OECD Social, Employment and Migration Working Papers, No. 163, OECD, Paris.

Chaudry, A.J., Wimer, C., Macartney, S., Frohlich, L., Campbell, C., Swenson, K., Oellerich, D. and Hauan, S. (2016). Poverty in the United States: 50-Year Trends and Safety Net Impacts, Office of the Assistant Secretary for Planning and Evaluation U.S. Department of Health and Human Services, Washington DC.

De Mello, L. and Dutz, M. eds (2012). Promoting Inclusive Growth: Challenges and Policies Paris: OECD.

Economic Report of the President (2015). Economic Report of the President Together With The Annual Report of the Council of Economic Advisers, Transmitted to the Congress February 2015, Council of Economic Advisers, Washington D.C. 
Fixler, D. and Jaditz, T. (2002). 'An examination of the difference between the CPI and the price deflator', BLS Working Paper no. 361, Bureau of Labor Statistics, Washington DC.

Fixler, D. and Johnson, D. (2014). 'Accounting for the Distribution of Income in the U.S. National Accounts', in D.W. Jorgenson, J. Landefeld, and P. Schreyer eds. Measuring Economic Sustainability and Progress, Cambidge, Mass.: NEBER, pp. 213-244.

Förster, M. and Tóth, I. (2015). 'Cross-country evidence of the multiple causes of inequality in the OECD area', in F. Bourguignon and A.B. Atkinson (eds.) Handbook of Income Distribution, Amsterdam: Elsevier, pp. 1729-1844.

Garfinkel, I., Rainwater L., and Smeeding T.M. (2006). 'A Reexamination of Welfare State and Inequality in Rich Nations: How In-Kind Transfers and Indirect Taxes Change the Story', Journal of Policy Analysis and Management 25 (4): 855-919.

Gasparini, L. and Tornarolli, L. (2015). 'Review of the OECD Income Distribution Database', Journal of Economic Inequality, 13 (4): 579-602.

Gornick, J. and Jäntti, M. (2013). Income Inequality: Economic Disparities and the Middle Class in Affluent Countries, Stanford: Stanford University Press.

IMF (2017). Fiscal Monitor: Tackling Inequality, International Monetary Fund, Washington D.C.

Jorgenson, D.W. and Slesnick, D. (2014). 'Measuring Social Welfare in the U.S. National Accounts', in D.W. Jorgenson, J. Landefeld, and P. Schreyer eds. Measuring Economic Sustainability and Progress, Cambridge, Mass.: NEBER, pp. 43-88.

Marical F., Mira d'Ercole, M., Vaalavuo, M. and Verbist, G. (2006). 'Publicly-provided Services and the Distribution of Resource', OECD Social, Employment and Migration Working Paper No. 45, Paris: OECD.

Morgan Stanley (2015). 'The Economic Costs of Inequality', January 2015, http://www.morganstanley.com/ideas/the-economic-cost-of-inequality/

Nolan, B. ed. (2018a). Inequality and Inclusive Growth in Rich Countries: Shared Challenges and Contrasting Fortunes, Oxford: Oxford University Press. 
Nolan, B. ed. (2018b). Generating Prosperity for Working Families in Affluent Countries, Oxford: Oxford University Press.

Nolan, B. and Förster, M. (2018). 'Inequality and Living Standards: Key Trends and Drivers', in Nolan ed. 2018a, pp. 11-40.

Nolan, B. and Thewissen, S. (2018a). 'The Evolution of Living Standards for Middle and Lower Income Households in OECD Countries', in B. Nolan ed., 2018, pp. 13-49.

Nolan, B. and Thewissen, S. (2018b). 'Inequality and Ordinary Living Standards in OECD Countries', in B. Nolan ed., 2018, pp. 49-84.

Nolan B. and Valenzuela, L. (2019). 'Inequality and its discontents', Oxford Review of Economic Policy, 35 (3), pp. 396-430.

Nolan, B., M. Roser and S. Thewissen (2018a). 'GDP Per Capita Versus Median Household Income: What Gives Rise to the Divergence Over Time and How Does This Vary Across OECD Countries?', Review of Income and Wealth, https://doi.org/10.1111/roiw.12362

Nolan, B., Roser, M. and Thewissen, S. (2018b). 'Median Household Income and GDP', in B. Nolan ed., 2018, pp. 85-110.

Nolan, B., Thewissen, S. and Lazzati, A. (2018). 'Sources of Household Income Growth in Rich Countries', in B. Nolan ed., 2018, pp. 111-133.

OECD (2008). Growing Unequal Paris: OECD.

OECD (2011). Divided We Stand: Why Inequality Keeps Rising Paris: OECD.

OECD (2015a). In It Together - Why Less Inequality Benefits All Paris: OECD.

OECD (2015b). All on Board: Making Inclusive Growth Happen Paris: OECD.

OECD (2016). The squeezed middle class in OECD and emerging countries: myth and reality, Paris: OECD.

Ostry et al., 2014; Ostry, J.D., Berg, A., and Tsangarides, C. (2014). 'Redistribution, Inequality, and Growth', IMF Staff Discussion Note, SDN/14/02, IMF, Washington D.C. 
Paulus, A., Sutherland, H. and Tsakloglou, P. (2010). 'The distributional impact of in kind public benefits in European countries', Journal of Policy Analysis and Management, 29 (2): 243-66.

Proctor, B.D., Semega, J.L. and Kollar, M.A. (2016). 'Income and Poverty in the United States: 2015', U.S. Census Bureau, Current Population Reports, P60-256(RV), U.S. Government Printing Office, Washington D.C.

Ravallion, M. (2015). 'The Luxembourg Income Study', Journal of Economic Inequality, $13(4), 527-547$.

Reich, R. (2015). Saving Capitalism: For the Many, Not the Few (New York: A. Knopf).

Smeeding, T.M, Tsakloglou, P. and Verbist, G. (2008). 'Distributional effects of public health care transfers in seven European countries', AIM-AP report, Institute for Social and Economic Research, University of Essex, Colchester. www.iser.essex.ac.uk/files/msu/emod/aimap/deliverables/AIM-AP1.3.pdf

Standard and Poor's (2014) "How Increasing Income Inequality Is Dampening U.S. Economic Growth, And Possible Ways To Change The Tide," August 2014. https://www.globalcreditportal.com/ratingsdirect/renderArticle.do?articleId=1351366\&SctAr

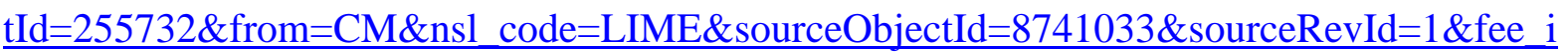
$\underline{\text { nd }=N \& \exp \text { date }=20240804-19: 41: 13}$.

Stiglitz. J. (2012). The Price of Inequality New York: W.W. Norton.

Stiglitz, J. (2015). The Great Divide: Unequal Societies and What We Can Do About Them New York: W.W. Norton.

Thewissen, S., L. Kenworthy, B. Nolan, M. Roser and T. Smeeding (2018). 'Rising Income Inequality and Living Standards in OECD Countries: How Does the Middle Fare?', Journal of Income Distribution, 26(2): 1-23.

Tóth, I. (2014). 'Revisiting Grand Narratives of Growing Inequalities: Lessons From 30 Country Studies', in B. Nolan, W. Salverda, D. Checchi, I. Marx, A. McKnight, I. G. Toth, and H. van de Werfhorst eds., Changing Inequalities and Societal Impacts in Rich Countries: Thirty Countries' Experiences, Oxford: OUP. 
Verbist, G., Förster, M. and Vaalavuo, M. (2012). 'The Impact of Publicly Provided Services on the Distribution of Resources: Review of New Results and Methods', OECD Social, Employment and Migration Working Papers, No. 130, OECD, Paris.

World Bank (2016). Poverty and Shared Prosperity 2016: Taking on Inequality, Washington D.C.: World Bank. 